\title{
Implementasi Model Pembelajaran Discovery Learning untuk Meningkatkan Aktivitas dan Hasil Belajar Matematika Siswa SD
}

\author{
Victoria Karjiyati \\ Universitas Bengkulu \\ vkarjiyati@gmail.com
}

\begin{abstract}
Abstack
This research aims to improve the activities and results of learning mathematics using the discovery learning model. This type of research is a classroom action research conducted in two cycles. Subjects of this study was grade III B SDIT Generasi Rabbani Bengukulu. The data collection instrument used student activity observation sheets and learning outcomes tests. The data analysis technique uses arithmetic mean and the percentage of learning completeness. The results showed: 1) Teacher activity in the first cycle obtained an average of 3.38 and in the second cycle an average of $3.81,2)$ Student activity in the first cycle obtained an average of 3.13 and in the second cycle an average of $3.67,3)$ Learning result in the first cycle were obtained an average of 71.43 with learning completeness $64.29 \%$, an increase in the second cycle obtained an average value of 76.79 with $82.14 \%$ completeness learning. The conclusion of this study that the use of the discovery learning model can increase the activity and learning result of class III B students of SDIT Generasi Rabbani, Bengkulu City
\end{abstract}

Keywords: discovery learning, activity, learning result, mathematics

\section{Pendahuluan}

Matematika merupakan salah satu bidang studi yang memiliki peranan penting dan wajib diajarkan di jenjang Sekolah Dasar. Matematika diperlukan oleh semua orang untuk membantu memecahkan masalah dalam kehidupan sehari-hari dan berguna sebagai penunjang penggunaan teknologi. Abidin (2018) menyatakan bahwa Matematika berguna untuk mengembangkan kemampuan berfikir dan memecahkan masalah, baik dalam matematika itu sendiri maupun bidang lain.

Salah satu tujuan pembelajaran matematika di Sekolah Dasar yaitu memahami konsep matematika dan keterkaitan antar konsep serta mengaplikasikan konsep atau algoritma secara luwes, akurat, efisiensi dan tepat dalam pemecahan masalah (Depdiknas,2006). Proses pembelajaran matematika menuntut kepiawaian dan kreativitas guru mulai dari merancang pembelajaran, melaksanakan pembelajaran hingga melakukan evaluasi.

Pembelajaran matematika akan berlangsung secara optimal jika pelajaran matematika dikaitkan dengan perkembangan mental siswa yang dimulai dari konsep yang sederhana hingga ke konsep yang rumit dan mulai dari konsep yang nyata ke konsep yang abstrak. Hal ini senada dengan pendapat Bruner (Muhsetyo, 2007) mengemukakan bahwa dalam pembelajaran matematika di sekolah dasar melalui tiga tahap, yaitu: 1) enaectiv yaitu memanipulasi objek secara langsung, 2) iconic yaitu memanipulasi objek tidak langsung atau melalui gambar, dan 3) 
symbolic yaitu memanipulasi simbol-simbol matematika yang bersifat abstrak. Pembelajaran matematika di sekolah dasar dapat berhasil dengan baik, jika dalam belajar dibantu dengan benda-benda konkrit yang ada di lingkungan sekitar. Pengalaman memanipulasi benda-benda konkret memiliki peranan penting dalam penanaman konsep matematika yang sesuai dengan tahap perkembangan siswa tingkat Sekolah Dasar. Hawa (2008) mengemukakan bahwa dalam proses pembelajaran matematika siswa diberi kesempatan memanipulasi benda-benda atau alat peraga yang dirancang dan bisa dikotak-katik oleh siswa dalam menemukan dan memahami konsep. Selanjudnya Trianto (2009) mengemukakan guru dapat menciptakan suatu kondisi belajar yang memadahi agar siswa mampu menemukan pengalaman-pengalaman nyata dan terlibat langsung dengan lingkungan.

Tingkat perkembangan anak pada usia SD berada pada tingkat operasional konkrit, artinya siswa mudah memahami suatu konsep jika mereka terlibat langsung memanipulasi benda-benda konkrit atau model tiruan. Pengalaman manipulasi benda-benda konkret memiliki peranan penting bagi tahap perkembangan siswa. Untuk itu pembelajaran matematika membutuhkan model pembelajaran yang dapat mengaktifkan siswa, sehingga siswa dapat lebih mudah menguasai konsep yang disajikan guru, yang pada akhirnya siswa dapat memperoleh hasil belajar yang lebih baik. Heruman (2007) menjelaskan bahwa dalam penanaman konsep matematika melalui tiga tahap, yaitu: 1) penanaman konsep dasar, ini merupakan jembatan yang menghubungkan kemampuan kognitif konkrit menuju ke abstrak, 2) pemahaman konsep, bertujuan agar siswa lebih memahami konsep matematika dan 3) pembinaan ketrampilan bertujuan agar siswa lebih terampil menggunakan berbagai konsep matematika untuk, memecahakan permasalahan sehari-hari.

Hasil observasi peneliti terhadap pembelajaran matematika di Kelas IIIB SDIT Generasi Rabbani Kota Bengkulu, ditemukan permasalahan sebagai berikut: 1) Proses pembelajaran yang dilakukan masih konvensional, yaitu guru memberikan contoh soal, menjelaskan cara menyelesaikan dan memberi latihan, 2) siswa kurang memperhatikan penjelasan guru dan sebagian siwa ribut, 3) siswa yang kurang paham dengan pelajaran, ketika diberi latihan hanya diam saja, 4) guru kurang memberikan bimbingan kepada siswa yang tidak mengerjakan soal. Nilai rata-rata rendah $(63,9)$ di2bawah KKM mata pelajaran matematika $(75,0)$. Rendahnya hasil belajar siswa diakibatkan pembelajaran yang dilakukan guru kurang menarik dan belum menggunakan model pembelajaran yang menyenangkan.

Menindaklanjuti permasalahan tersebut peneliti berkolaborasi dengan kepala sekolah dan guru kelas melakukan diskusi untuk mencari solusi pemecahan masalah. Hasil diskusi disepakati untuk mengatasi permasalahan pembelajaran matematika digunakan model pembelajaran inovatif yang dapat mengaktifkan siswa yaitu menggunakan model discovery learning. Model Discovery Learning merupakan salah satu model yang memungkinkan siswa terlibat secara langsung dalam proses pembelajaran sehingga mampu menggunakan proses mentalnya untuk menemukan suatu konsep yang dipelajari (Ilahi, 2012). Selanjutnya Winarni (2012) mengemukakan bahwa model pembelajaran discovery learning sebagai proses pembelajaran yang penyajian materi tidak dalam bentuk final, melainkan siswa didorong untuk mengidentifikasi apa yang ingin diketahui dan mencari informasi sendiri, kemudian mengorganisasi atau membentuk apa yang diketahui dan apa yang dipahami dalam bentuk akhir.

Penerapan model discovery learning dalam pembelajaran matematika diharapkan dapat mengubah pembelajaran yang pasif menjadi aktif. Siswa dimotivasi terlibat secara aktif dan kreatif dalam menemukan konsep-konsep matematika. Melalui pembelajaran menggunakan discovery learnig diharapkan dapat meningkatkan 
aktivitas dan hasil belajar. Didukung penelitian Pakpahan (2014) menunjukkan bahwa dengan menggunakan model discovery learning dapat meningkatkan hasil belajar siswa. Hasil penelitian menunjukkan pada siklus I diperoleh $43,3 \%$ siswa telah mencapai KKM dan meningkat pada siklus ke II diperoleh 90\% siswa telah mencapai KKM. Selanjutnya hasi penelitian Utama (2019) menunjukkan bahwa penerapan model pembelajaran menggunakan discovery learning dapat meningkatkan hasil belajar, terbukti dari ketuntasan belajar pada siklus I 65,5\% meningkat menjadi $82,70 \%$.

Menurut Syah (20040) langkah-langkah model pembelajaran discovery learning adalah sebagai berikut: 1) Stimulasi/ pemberian rangsangan, pada tahap ini siswa dihadapkan pada suatu objek yang dapat menimbulkan tanda tanya dan keingintahuan yang tinggi, 2) Identifikasi masalah, pada tahap ini siswa diberi kesempatan mengidentifikasi sebanyak mungkin masalah yang relevan dan membuat hipotesis, 3) Pengumpulan data, pada tahap ini siswa diminta mengumpulkan yang relevan sebanyak-banyaknya untuk menjawab pertanyaan, 4) Pengolahan data, pada tahap ini semua informasi yang terkumpul diolah, ditabulasi, dihitung dengan cara tertentu sebagai pembentukan konsep dan generalisasi, 5) Pembuktian, pada tahap ini siswa mengecek atau melakukan pemeriksaan secara cermat untuk membuktikan benar tidaknya hipotesis yang sudah ditetapkan, 6) Menarik kesimpulan, pada tahap ini siswa dibimbing dapat menarik kesimpilan yang dapat dijadikan prinsip umum dan berlaku untuk masalah yang sama.

\section{Metode}

Jenis penelitian yang digunakan adalah penelitian tindakan kelas (clasroom Action research), yang dilakukan sebanyak dua siklus. Setiap sikklus terdiri dari tahap perencanaan, tindakan, pengamatan dan refleksi. Penelitian ini untuk membantu memecahkan masalah dan memperbaiki proses pembelajaran matematika secara reflekstif dan kolaboratif. Subyek penelitian ini adalah siswa kelas IIIB SDIT Generasi Rabbani kota Bengkulu yang berjumlah 28 orang, terdiri 16 siswi dan 12 siswa.

Instrumen yang digunakan dalam penelitian ini adalah lembar observasi aktivitas guru dan aktivitas siswa serta lembar tes. Lembar observasi aktivitas guru dan siswa digunakan untuk melihat aktivitas selama proses pembelajaran. Sedangkan lembar tes digunakan untuk mengukur keberhasilan siswa dalam menguasai konsep atau hasil belajar. Teknik analisis lembar observasi aktivitas guru dan siswa menggunakan perhitungan rata-rata, sedangkan untuk mengolah data hasil tes mengunakan perhitungan rata-rata dan persentase ketuntasan belajar.

\section{Hasil}

\section{Siklus I}

Pembelajaran siklus I membahas tentang perkalian dua bilangan yang terdiri dua angka dengan satu angka. Langkah-langkah penelitian dilakukan sebagai berikut: perencanaan, tindakan, observasi dan refleksi.

\section{Tahap Perencanaan}

Dalam perencanaan siklus I meliputi : 1) menyusun RPP menggunakan model discovery learning pada materi perkalian dua bilangan terdiri dua angka dengan satu angka, 2) Meyiapkan media membelajaran berupa PPT tentang gambargambaran transfortasi dan table takaltar, 3) Menyusun Lembar Kerja Peserta Didik (LKPD), 4) Menyiapkan lembar observasi aktivitas guru dan siswa, 5)menyiapkan soal evaluasi. 


\section{Pelaksanaan Tindakan}

Langkah-langkah tindakan yang dilakukan guru sebagai berikut: 1) Tahap Stimulasi, pada tahap ini guru memberikan stimulus atau rangsangan sesuai dengan materi perkalian, siswa diminta mengamati tayangan berbagai gambar alat transportasi seperti: mobil, becak, sepeda, dengan tujuan untuk mematovasi siswa melakukan eksplorasi dan memunculkan pertanyaan-pertanyaan, 2) Tahap idientifikasi masalah, pada tahap ini siswa diberi kesempatan untuk mengidentifikasi sebanyak mungkin permasalahan dan bahan yang relevan dengan tanyangan gambar alat transportasi. Permasalahan yang dipilih dibuat pernyataan sebagai jawaban sementara, 3) Tahap mengumpulkan data, pada tahap ini siswa dimotivasi untuk mengumpulkan informasi dari buku yang digunakan untuk menjawab pertanyaan yang dibuat, 4) Tahap pengelolahan data, pad tahap ini siswa diberi kesempatan melakukan diskusi mengkunakan LKPD yang sudah disipkan guru untuk menemukan konsep perkalian, prosedur menyelesaikan perkalian. Dalam diskusi siswa dibantu dengan menggunakan table perkalian pintar (takaltar), 5) Tahap pembuktian, pada tahap ini siswa melakukan pemeriksaan kembali untuk membuktikan apakah jawaban sudah benar atau belum melalui menghitung ulang. Siswa diminta untuk mempresentasikan hasil diskusi dan siswa yang lain memberi tanggapan. Selanjutnya guru memberikan pemantapan materi yang dibahas, 6) Tahap menarik kesimpulan, pada tahap ini siswa diminta membuat kesimpulan tentang materi yang dibahas.

\section{Tahap Observasi}

Pelaksanaan observasi dilakukan oleh guru dan kepala sekolah dengan menggunakan lembar observasi aktivitas guru dan siswa. Selama proses pempelajaran observer mencatat aktivitas guru meliputi: 1) memfasilitasi siswa melakukan tanya jawab, 2) memfasilitasi siswa berdiskusi, 3) memfasilitasi siswa presentasi hasil diskusi dan 4) memfasilitasi siswa menyelesaikan tugas. Hasil pengolahan data aktivitas guru disajikan pada tabel berikut :

Tabel 1. Hasil Observasi Aktivitas Guru Siklus I

\begin{tabular}{cccc}
\hline Materi & Observer & Skor & Kriteria \\
\hline Perkalian & I & 3,50 & Baik \\
\cline { 2 - 4 } & II & 3,25 & Baik \\
\hline Rata -rata & & 3,38 & Baik \\
\hline
\end{tabular}

Berdasarkan tabel di atas observer 1 memberikan skor 3,5 dan observer 2 memberikan skor 3,25. Rata-rata skor dari kedua observer diperoleh 3,38 pada kriteria baik.

Selanjudnya aktivitas siswa meliputi: 1) melakukan tanya jawab, 2) melaksanakan diskusi, 3) presentasikan hasil diskusi dan 4) menyelesaikan tugas. Adapun hasil aktivitas siswa disajikan pada tabel berikut:

Tabel 2. Hasil Observasi Aktivitas Siswa Siklus I

\begin{tabular}{cccc}
\hline Materi & Observer & Skor & Kriteria \\
\cline { 2 - 4 } Perkalian & I & 3,25 & Baik \\
\cline { 2 - 4 } & II & 3,0 & Baik \\
\hline Rata -rata & & 3,13 & Baik \\
\hline
\end{tabular}

Berdasarkan tabel di atas observer 1 memberikan skor 3,25 dan observer 2 memberikan skor 3,0. Rata-rata skor dari kedua observer diperoleh 3,13 pada kriteria baik. 
Di akhir pembelajaran siswa diberikan soal tes untuk mengetahui tingkat keberhasilan proses pembelajaran siklus I. Hasil analisis pengolahan data hasil belajar siswa siklus I disajikan pada tabel berikut.

Tabel 3. Hasil Belajar Siswa Siklus I

\begin{tabular}{cc}
\hline Uraian & Hasil \\
\hline Jumlah siswa yang ikut tes & 28 \\
\hline Skor Terendah & 30 \\
\hline Skor Tertinggi & 100 \\
\hline Jumlah skor & 2000 \\
\hline Rata-rata skor & 71,43 \\
\hline Jumlah siswa yang tuntas & 18 \\
\hline Jumlah siswa yang tidak tuntas & 10 \\
\hline Persentase ketuntasan & $64,29 \%$ \\
\hline Keterangan & Belum tuntas
\end{tabular}

Berdasarkan tabel di atas siswa yang ikut tes berjumlah 28 orang dengan perolehan nilai terendah 30 dan nilai tertinggi 100. Hasil rata-rata nilai 71,43. Dari 28 siswa yang mencapai ketuntasan belajar sejumlah 18 orang dan yang tidak mencapai ketuntasan 10 orang dengan persentase ketuntasan belajar $64,29 \%$ dengan kriteria belum tuntas.

\section{Refleksi}

Pada tahap refleksi ini Kepala Sekolah, guru dan peneliti melakukan diskusi untuk mengetahui kelebihan dan kekurangan selama proses pembelajaran. Dari hasil diskusi ditemukan kelebihan pembelajaran siklus I, yaitu : 1) guru sudah memotivasi dan memfasilitasi siswa melakukan Tanya jawab dengan baik, 2) guru membimbing siswa mempresentasikan hasil diskusi dengan baik, 3) sebagian siswa sudah berani mengajukan pertanyaan dan memberikan tanggapan, 4) ketika presentesi siswa sudah mampu mempresentasi dengan runtus dan sistimatis, 5) Nilai siswa yang mencapai KKM sebanyak 18 orang.

Adapun kelemahan, sebagai berikut: 1) guru belum memberikan bimbingan diskusi secara maksimal, 2)ketika diskusi lebih didominasi siswa yang pintar dan siswa lain ribut, 3) sebagian siswa masih pasip, 4)masih ada 10 siswa yang nilainya di bawah KKM, 4) siswa kesulitan menemukan konsep.

\section{Siklus II}

\section{Tahap Pesiapan}

Persiapan yang dilakukan guru yaitu: 1) menyusun RPP menggunakan model discoveri learning dengan materi soal cerita yang berkaian dengan perkalian, 2) Membuat Lembar Kerja Peserta Didik (LKPD), 3) Menyiapkan lembar obsevasi aktivitas siswa, 4) Meyiapkan tes evaluasi.

\section{Tahap Tindakan}

Langkah langkah yang dilakukan guru dalam pelaksanaan bembelajaran sebagai berikut: 1) Pada tahap stimulasi guru menayangkan gambar sekelompok siswa yang antri naik bis untuk pergi bertamasya. Dari gambar tersebut siswa diajak mengamati dan melakukan eksplorasi, 2) Tahap identifikasi masalah, pada tahap ini guru memotivasi siswa untuk memunculkan pertanyaan-pertanyaan dan tanggapan tentang obyek yang diamati , 3) Tahap mengumpulkan data, pada tahap ini siswa dimotivasi mencari data-data yang ada pada gambar, mencari informasi dari buku yang berhubungan dengan prosedur menyelesaikan soal cerita, 4)Tahap pengolahan data, pada tahap ini guru meminta siswa berdiskusi menyelesaikan permasalahan yang di LKPD, 5)Tahap Pembuktian, pada tahap ini setiap kelompok diminta mempresentasikan hasil diskusi dan kelompok lain menangapi dan dilanjutkan guru memberikan pemantapan materi, 6) Tahap menarik kesimpulan, pada tahap ini guru 
membimbing siswa menyimpulkan materi pelajaran dan dilanjutan memberikan tes evaluasi.

\section{Tahap Observasi}

Pada tahap ini, guru kelas dan kepala sekolah mengamati aktivitas guru dan siswa selama proses pembelajaran. Hasil pengolahan data aktivitas guru siklus II disajikan pada tabel berikut:

Tabel 4. Hasil Observasi Aktivitas Guru Siklus II

\begin{tabular}{cccc}
\hline Materi & Observer & Skor & Kriteria \\
\cline { 2 - 4 } Perkalian & I & 3,75 & Sangat Baik \\
\cline { 2 - 4 } & II & 3,87 & Sangat Baik \\
\hline Rata -rata & & 3,81 & Sangat Baik \\
\hline
\end{tabular}

Berdasarkan tabel di atas observer 1 memberikan skor 3,75 dan observer 2 memberikan skor 3,87. Rata-rata skor dari kedua observer diperoleh 3,81 pada kriteria sangat baik.

Adapun hasil pengolahan data aktivitas siswa siklus II disajikan pada tabel berikut.

Tabel 5. Hasil Observasi Aktivitas Siswa Siklus II

\begin{tabular}{cccc}
\hline Materi & Observer & Skor & Kriteria \\
\cline { 2 - 4 } Perkalian & I & 3,70 & Sangat Baik \\
\cline { 2 - 4 } & II & 3,62 & Sangat Baik \\
\hline Rata -rata & & 3,67 & Sangat Baik \\
\hline
\end{tabular}

Berdasarkan tabel di atas observer 1 memberikan skor 3,70 dan observer 2 memberikan skor 3,62. Rata-rata skor dari kedua observer diperoleh 3,67 pada kriteria baik.

Di akhir pembelajaran siswa diberikan soal tes untuk mengetahui tingkat keberhasilan proses pembelajaran siklus II. Hasil analisis pengolahan data hasil belajar siswa siklus II disajikan pada tabel berikut:

Tabel 6. Hasil Belajar Siswa Siklus II

\begin{tabular}{cc}
\hline Uraian & Hasil \\
\hline Jumlah siswa yang ikut tes & 28 \\
\hline Skor Terendah & 30 \\
\hline Skor Tertinggi & 100 \\
\hline Jumlah skor & 2015 \\
\hline Rata-rata skor & 76,79 \\
\hline Jumlah siswa yang tuntas & 23 \\
\hline Jumlah siswa yang tidak tuntas & 5 \\
\hline Persentase ketuntasan & $82,14 \%$ \\
\hline Keterangan & Tuntas
\end{tabular}

Berdasarkan tabel di atas siswa yang ikut tes berjumlah 28 orang dengan perolehan nilai terendah 30 dan nilai tertinggi 100. Perolehan hasil rata-rata nilai 76,79. Dari 28 siswa yang mencapai ketuntasan belajar sejumlah 23 orang dan yang tidak mencapai ketuntasan 5 orang dengan persentase ketuntasan belajar 82,14\% dengan kriteria tuntas.

Tahap Refleksi

Peneliti, guru kelas dan kepala sekolah melakukan diskusi untuk menemukan kelebihan dan kekuranga. Kelebihan pada siklus II ini siswa sudah terlibat aktif bertanya dan menanggapi pertanyaan, siswa sudah terlibat aktif berdiskusi, presenatasi sudah lancar, dan menyelesaikan tugas dengan baik. Adapun 
kelemahannya masih 5 siswa yang mendapat nilai kurang dari KKM dan perlu bimbingan secara khusus.

\section{Pembahasan}

Penelitian Tindakan Kelas ini berlangsung dua siklus. Pembelajaran pada siklus I membahas materi perkalian dua angka dengan satu angka. Pada tahap stimulasi guru menayangkan gambar alat transportasi dan meminta siswa melakukan Tanya jawab. Siswa antusias mengajukan Tanya jawab dan terlibat aktif mengikuti pelajaran. Selanjudnya guru memberikan tugas LKPD untuk didiskusikan . Dalam diskusi belum semua siswa terlibat aktif mengerjakan tugas. Selesai diskusi, guru meminta siswa mempresentasikan hasil diskusi. Setiap wakil kelompok presentasi dengan baik dan siswa lain memperhatikan.Kegitan pembelajaran diakhiri dengan guru meminta siswa membuat kesimpulan dan mengerjakan soal tes.

Hasil analisis pengolahan data aktivitas guru dari dua observer yaitu 3,38 pada katagori baik dan aktivitas siswa 3,13 pada kreteria baik. Dari hasil refleksi, pada aktivitas guru perlu perbaikan dalam pembimbingan diskusi kelompok dan pembimbingan secara khusus bagi siswa yang belum menguasai materi, sedangkan pada aktivitas siswa masih perlu memberikan bimbingan dalam diskusi dan melibatkan seluruh siswa secara aktif. Sesuai hasil penelitian Istiana (2015) mengemukakan bahwa aktivitas belajar siswa merupakan hal yang penting dalam proses pembelajaran.

Dari hasil belajar diperoleh rata-rata 71,43 dengan ketuntasan belajar 64,29\%. Masih ada 10 siswa yang belum tuntas. Model Discovery Learning lebih menekankan pada penemuan konsep, siswa didorong untuk mengidientifikasi dan mengkontruksi suatu konsep. Sesuai pendapat Bruner dalam Winarni(2012) menyatakan bahwa proses belajar akan berjalan dengan baik jika guru memberikan kesempatan kepada siswa untuk lebih kreatif dalam menemukan suatu konsep, teori, aturan, atau pemahaman melalui contoh-contoh yang dijumpai dalam kehidupan sehari-hari.

Pada siklus kedua membahas materi soal cerita berkaitan dengan perkalian. Pada tahap stimulasi siswa terbibat aktif dan bersemangat melakukan Tanya jawab. Selanjudnya guru membagikan LKPD untuk bahan berdiskusi. Selama diskusi guru memberikan bimbingan, sehingga siswa terlihat gembira dan semangat mengerjakan tugas. Siswa sudah memahami cara menyelesaikan soal cerita menggunakan prosedur pemecahan masalah. Menurut Polya dalam Winarni (2011) mengemukakan bahwa dalam menyelesaikan masalah menggunakan langkahlangkah sebagai berikut: 1) memahami masalah, artinya mengerti masalah dan tahu apa yang dikehendaki, 2) perencanaan pemecahan masalah, 3) melaksanakan perencanaan pemecahan masalah dan 4)melihat kembali kelengkapan pemecahan masalah

Hasil analisis pengolahan data aktivitas guru pada siklus II dari dua observer yaitu 3,81 dengan kriteria sangat baik, sedangkan aktivitas siswa yaitu 3,67 dengan kriteria sangat baik. Sudjana (2009) menyatakan bahwa penilaian proses pembelajaran adalah untuk melihat sejauh mana keterlibatan siswa dalam mengikuti proses pembelajaran. Keaktifan ini bisa dilihat dari keempat aspek, yaitu: aktivitas melakukan Tanya jawab, melakukan diskusi, melakukan presentasi dan menyelesaikan tugas. Dari analisis hasil belajar siklus II diperoleh rata-rata 76,79 dengan persentase ketuntasan belajar $82,14 \%$ dengan kriteria tuntas. Sesuai pendapat Sudjana (2009) menyatakan bahwa hasil belajar adalah kemampuan yang dimiliki siswa setelah menerima pengalaman belajar. 
Proses pembelajaran menggunakan Discovery Learning dapat meningkatkan aktivitas pembelajaran. Aktivitas guru pada siklus I diperoleh skor 3,38 pada kreteria baik, meningkat pada siklus II menjadi 3,81 pada kreteria sangat baik. Aktivitas siswa pada siklus I diperoleh skor 3,13 dengan kriteria baik meningkat pada siklus II menjadi 3,67 dalam kriteria sangat baik.Didukung hasil penelitian Purnawati (2018) menunjukkan bahwa dengan menggunakan model discovery learning dapat menciptakan suasana belajar menjadi lebih aktif, terbukti aktivitas siswa siklus I pada pertemuan I 69,56\% dengan kriteria baik dan pertemuan ke-II $78,26 \%$ pada kriteria baik meningkat pada siklus ke-II pada pertemuan I $70.0 \%$ dengan kriteria cukup baik meningkat menjadi 80\% dengan kriteria baik.

Proses pembelajaran mengunakan model Discovery Learning dapat meningkatkan penguasaan konsep yang ditandai dengan keberhasilan belajar. Hasil analisis data menunjukkan bahwa pada siklus I diperoleh rata-rata 71,43 dengan ketuntasan belajar $64,29 \%$ meningkat pada siklus II dengan nilai rata-rata 76,79 dengan ketuntasan belajar $82,14 \%$. Sesuai dengan penelitian Supriyanto (2014) menunjukkan bahwa ada peningkatan hasil belajar yaitu hasil belajar pada siklus I diperoleh $60,6 \%$ meningkat menjadi $90.9 \%$ pada siklus II.

\section{Simpulan}

Berdasarkan hasil penelitian dapat disimpulkan , sebagai berikut: 1)Penerapan model Discovery Learning dapat meningkatkan aktivitas guru, yang dibuktikan perolehan nilai rata- rata skor sikluske-I, yaitu 3,38 berada pada kategori baik, meningkat pada siklus II menjadi 3,81 pada kategori sngat baik, 2)Perolehan ratarata aktivitas siswa siklus I, yaitu 3,13 pada katagori baik, meningkat pada siklus II menjadi 3,67 pada katagori sangat baik, 3) Penerapan model Discovery Learning dapat meningkatkan hasil belajar matematika, pada siklus ke-I diperroleh rat-rata 71,43 dengan ketuntasan belajar 64,29\% meningkat pada siklus ke-II menjadi 76,79 dengan ketuntasan belajar $82,14 \%$.

\section{Ucapan Terima Kasih}

Peneliti mengucapkan terimakasih kepada Belmawa yang telah memberikan hibah Penugasan Dosen ke Sekolah (PDS) dan kepada Kepala Sekolah, dewan guru serta semua pihak SDIT Generasi Rabbani Kota Bengkulu yang telah membantu terlaksananya penelitian.

\section{Referensi}

Abidin.Y, Mulyati. T, Yunansah. H. (2018). Srategi Meningkatkan Kemampuan Literasi Matematika, Sains, Membaca dan menulis. Jakarta: Bumi Aksara.

Depdiknas. (2006). Pedoman Penyusunan Kurikulum Tingkat Satuan Pendidikan di Sekolah Dasar. Jakarta: Badan Standar Nasional Pendidikan.

Heruman. (2007). Model Pembelajaran Matematika di Sekolah Dasar. Bandung : PT Remaja Rosdakarya.

Ilahi, M., T. (2012). Pembelajaran Discovery Strategy dan mental Vocational Skill. Yogyakarta: Diva Press.

Musetyo, G. (20070. Pembelajaran Matematika SD. Jakarta: Universitas Terbuka.

Karso, Suryadi. G., Musetyo. G., Tjandra, T., D., Widagdo, D., \& Priyatna, N. (2011). Pendidikan Matematika II. Jakarta: Universitas Terbuka.

Pakpahan. R. (2014). Meningkatkan Hasil Belajar Siswa dengan Menggunakan Metode Discovery Learning pada Mata Pelajaran Matematika Kelas IV SD 
Untemungkur Kecamatan Kolang Kabupaten Tapanulin Tengah. School Education Journal PGSD FKIP Unimed, 1, (2).

Purnawati, R., R. Meningkatkan Hasil Belajar Matemnatika Siswa SD kelas IV Menggunakan Model Pembelajaran Discovery Learning Berbasis Kurikulum 2013. Jurnal Pendidikan Berkarakter FKIP UM Mataram, 1, (1).

Syah. (2004). Psikologi Pendidikan dengan Pendekatan Baru. Bandung: PT Remaja Rosdakarya.

Sudjana, N. (2009). Penilaian Proses Hasil Belajar Mengajar. Bandung: PT Remaja Rosdakarya.

Supriyanto, B. (2014). Penerapan Discovery Learning untuk Meningkatkan Hasil Belajar Siswa Kelas VI B Mata Pelajaran Matematika Pokok Bahasan Keliling dan Luas Lingkaran di SDN Tanggul Wetan 02 Kecamatan Tanggul Kabupaten Jember. Pancaran Pendidikan, 3, (2).

Trianto. (2009). Mendesaian Model Pembelajaran Inovatif-Progresif: Konsep, Landasan, dan Implementasinya Pada Kurikulum Tingkat Satuan Pendidikan. Jakarta: Kencana 2010.

Utama, L., V. (2019). Peningkatan Hasil Belajar Materi Keliling dan Luas Bangun Datar Melalui Model Discovery Learning pada Siswa Kelas IVA Sekolah Dasar Ngaglik. Jurnal Pemikiran dan Pengembangan Sekolah Dasar, 7, (1).

Winarni. E., W. (2012). Inovasi Pembelajaran IPA. Bengkulu: FKIP Unib Press.

Winarni, E., S. (2011). Matematika Untuk PGSD. Bandung: PT Remaja Rosdakarya. 